Article

\title{
Alpha and Beta-diversity of Microbial Communities Associated to Plant Disease Suppressive Functions of On-farm Green Composts
}

\author{
Catello Pane ${ }^{1, *(\mathbb{D})}$, Roberto Sorrentino ${ }^{1}{ }^{(D}$, Riccardo Scotti ${ }^{1}$, Marcella Molisso ${ }^{2}$, \\ Antonio Di Matteo $^{2} \mathbb{D}$, Giuseppe Celano ${ }^{3}$ and Massimo Zaccardelli ${ }^{1}$ \\ 1 Consiglio per la Ricerca in Agricoltura e l'Analisi dell'Economia Agraria, Centro di ricerca Orticoltura e \\ Florovivaismo, via Cavalleggeri 25, 84098 Pontecagnano Faiano, Italy; roberto.sorrentino@crea.gov.it (R.S.); \\ riccardo.scotti@quadram.ac.uk (R.S.); massimo.zaccardelli@crea.gov.it (M.Z.) \\ 2 Dipartimento di Agraria, Università degli Studi di Napoli Federico II, via Università 100, 80055 Portici, Italy; \\ marcella.molisso@gmail.com (M.M.); antonio.dimatteo@unina.it (A.D.M.) \\ 3 Dipartimento di Farmacia, Università degli Studi di Salerno, via Giovanni Palo II 132, 84084 Fisciano, Italy; \\ gcelano@unisa.it \\ * Correspondence: catello.pane@crea.gov.it; Tel.: +39-089-386-239
}

Received: 24 December 2019; Accepted: 30 March 2020; Published: 4 April 2020

\begin{abstract}
Green waste composts are obtained from agricultural production chains; their suppressive properties are increasingly being developed as a promising biological control option in the management of soil-borne phytopathogens. The wide variety of microbes harbored in the compost ecological niches may regulate suppressive functions through not yet fully known underlying mechanisms. This study investigates alpha- and beta-diversity of the compost microbial communities, as indicators of the biological features. Our green composts displayed a differential pattern of suppressiveness over the two assayed pathosystems. Fungal and bacterial densities, as well as catabolic and enzyme functionalities did not correlate with the compost control efficacy on cress disease. Differences in the suppressive potential of composts can be better predicted by the variations in the community levels of physiological profiles indicating that functional alpha-diversity is more predictive than that which is calculated on terminal restriction fragments length polymorphisms (T-RFLPs) targeting the 16S rRNA gene. However, beta-diversity described by nMDS analysis of the Bray-Curtis dissimilarity allowed for separating compost samples into distinct functionally meaningful clusters and indicated that suppressiveness could be regulated by selected groups of microorganisms as major deterministic mechanisms. This study contributes to individuating new suitable characterization procedures applicable to the suppressive green compost chain.
\end{abstract}

Keywords: biological control; damping-off; microbiome; soil ecology

\section{Introduction}

Soil-borne fungal diseases are among the main and most feared factors limiting agricultural production and economic sustainability: they are responsible for severe outbreaks that are difficult to eradicate without the massive use of high-impacting synthetic fungicides. Public concerns about environmental and health risks linked to the indiscriminate use of these are prompting the setup and implementation of effective nonchemical technologies for developing ecofriendly disease control methods that include biological, agronomic and genetic means. Compost may enhance the sustainability of intensive agricultural systems through its natural suppressiveness properties [1]. Suppressiveness occurs when compost interferes in the compatible plant-pathogen interaction, generating conditions unfavorable to the pathogenesis [2]. A quality compost may constitute the 
eligible habitat for many microbial species with different lifestyles, which impact significantly on yields, quality and healthiness of vegetable crops, with a harmonious use of natural resources, biodiversity and ecosystem processes [3]. These compost-borne microorganisms facilitate many ecosystem functions that generate some fundamental services for people's well-being [4] and provide regulating services that are noticeable for agriculture sustainability, such as plant nutrient availability, soil regeneration and natural suppression of soil-borne phytopathogens [5]. Compost may act through its microbial components directly towards the pathogen by typical antagonistic mechanisms or on the plant by inducing systemic resistance or stimulating in it an enhanced physiological status [6].

On-farm composting is a sound and cost-effective technology that allows for the recycling of agricultural biomasses within the farm to be used as quality compost in future cropping cycles [7]. The biochemical thermo-oxidative process is carried out by the microorganisms that, over time, change the organic matter composition; the latter, consequently, conditions the structure of the resident microbial community $[8,9]$. In the framework of the CarbOnFarm project, an on-farm composting plant has been realized on a surface of five thousand square meters, to service a farmer's organization that cooperates in Southern Italy, to compost agricultural residues and pruning biomasses [10]. Many investigations about microbiota composition and structures are still ongoing to find microbiological markers able to define intrinsic compost characteristics [11]; So, these could be useful if associated with the beneficial properties on plants.

Here, a set of 13 on-farm composts, obtained from agricultural waste recycling, were evaluated for suppressiveness against the soil-borne pathogens Rhizoctonia solani and Sclerotinia minor on the common host, Lepidium sativum by suppressive compost bioassay in an artificially inoculated amended media. Examination at metabolic and genetic level aimed at revealing changes in the structure of the microbial communities inhabiting composts helped to understand their role in modulating disease suppression.

\section{Materials and Methods}

\subsection{Compost Collection}

In this study, 13 on-farm composts (coded from C1 to C13), were used. The composts were obtained through composting of raw agricultural materials aerated first by mechanical turning, and on static piles by basal forced ventilation along 45 -day active phase, followed by a two months-curing period. Feedstock used in compost piles were composed as follow: $\mathrm{C} 1$ - leafy vegetables, fennel and woodchips; C2 - maize, livestock waste and woodchips; C3 - leafy vegetables, basil, tomato, watermelon and woodchips; C4 - leafy vegetables, basil, watermelon and woodchips; C5 - leafy vegetables, basil, pumpkin and woodchips; C6 - leafy vegetables, basil and woodchips; C7 - leafy vegetables, basil, watermelon and woodchips; C8 - leafy vegetables, basil and woodchips; C9 - leafy vegetables, basil and woodchips; C10 - leafy vegetables, basil, pumpkin and woodchips; C11 - leafy vegetables, artichoke and woodchips; C12 - leafy vegetables, cabbage, walnut husk and woodchips; C13 - leafy vegetables, basil, sorghum, tomato, pumpkin and woodchips. During the thermophilic phase, pile heating reached up to $60^{\circ} \mathrm{C}$ and stayed for about 4 days, to achieve biomasses sanitation. For all the microbiological analyses and for the DNA extraction, compost sampling was carried out by pooling and mixing 10 subsamples taken by a small shovel at $0.5-1.0 \mathrm{~m}$ depth, from 10 different points of each compost pile (dimension $1.5 \mathrm{~m} \times 30 \mathrm{~m}$ ). Then, samples were stored at $4{ }^{\circ} \mathrm{C}$, while for the molecular study, a representative aliquot was stored at $-80^{\circ} \mathrm{C}$ until DNA extraction.

\subsection{Compost Suppressive Assay}

Plant fungal pathogens used in this study were R. solani (AG-4) and S. minor [8], maintained on potato dextrose agar medium (PDA, Oxoid) in the fungi collection of CREA-Research centre for vegetables and ornamental crops (Pontecagnano Faiano, Italy). The ability of the different composts to suppress R. solani and S. minor damping-off was assessed by evaluating the L. sativum damping off occurrence in artificially inoculated amended media [2]. Potting-mixtures were prepared by amending 
autoclaved soil peat with $20 \%(\mathrm{v} / \mathrm{v})$ of both sterile (twice autoclaved) or not sterile compost, while pots fully filled only with sterilized peat were used as the nonamended control. The experimental design included five pots per treatment, and the experiment was repeated twice. After 7 days, incubation disease incidence was assessed as the percentage of damped-off seedlings and the compost control efficacy was calculated as described by Shin et al. [12] using the following formula: Control efficacy (\%) $=100-(100 \times$ disease incidence of treatment/disease incidence of control $)$.

\subsection{Assessment of Compost Phytotoxicity}

Compost phytotoxicity was assessed on cress seeds soaked with compost water extracts (at 50, 16.6 and $5 \mathrm{~g} \mathrm{~L}^{-1}$ ), by measuring germination and root elongation of seedlings and compared to the water control. The number of germinated seeds and the root length, recorded after $36 \mathrm{~h}$, were used to calculate the germination index $(\mathrm{GI} \%)$ with the following formula: GI\% $=[(\mathrm{n}$. germinated seeds on extracts $/ \mathrm{n}$. of germinated seeds on water $) \times($ Mean root length on extracts/Mean root length on water $)] \times 100$.

\subsection{Microbiologial Characterization of Compost}

\subsubsection{Population Counting}

The abundance of culturable filamentous fungi and total bacteria in compost samples was evaluated by serial ten-fold $\left(10^{-1}\right.$ to $\left.10^{-7}\right)$ dilution method in three replicates with three independent samples. Fungi were counted on PDA (Oxoid) pH 6, and supplemented with $150 \mathrm{mg} \mathrm{L}^{-1}$ of nalidixic acid and $150 \mathrm{mg} \mathrm{L}^{-1}$ of streptomycin. Total bacteria were counted on selective medium (glucose $1 \mathrm{~g} \mathrm{~L}^{-1}$, proteose peptone $3 \mathrm{~g} \mathrm{~L}^{-1}$, yeast extract $1 \mathrm{~g} \mathrm{~L}^{-1}, \mathrm{~K}_{2} \mathrm{PO}_{4} 1 \mathrm{~g} \mathrm{~L}^{-1}$, agar $15 \mathrm{~g} \mathrm{~L}^{-1}$ ) supplemented with actidione $100 \mathrm{mg} \mathrm{L}^{-1}$. Peudomonads were counted on selective agar medium without iron, supplemented with actidione, while spore-forming Bacillus-like bacteria were counted by plating eluates previously heated at $90{ }^{\circ} \mathrm{C}$ for $10 \mathrm{~min}$, on Nutrient Agar [8]. Population densities are reported as Log c.f.u. $\mathrm{g}^{-1}$ dry weight of compost.

\subsubsection{Enzymatic and Metabolic Analysis}

Fluorescein diacetate (FDA) hydrolysis was assessed on three independent $2.5 \mathrm{~g}$ compost samples, each supplemented with $15 \mathrm{~mL}$ of $0.2 \mathrm{M}$ potassium phosphate buffer, $\mathrm{pH}$ 7.6. Enzymatic reaction was started by adding $0.5 \mathrm{~mL}$ FDA solution $\left(2 \mathrm{mg} \mathrm{mL}^{-1}\right)$. The sample was shaken for $2 \mathrm{~h}$ in an orbital incubator and hydrolysis reaction was stopped by adding $15 \mathrm{~mL} \mathrm{CHCl}_{3} / \mathrm{CH}_{3} \mathrm{OH}(2: 1 \mathrm{v} / \mathrm{v})$. Following centrifugation $(700 \times g)$ and filtration of the aqueous phase, the absorbance of filtrates was measured at $490 \mathrm{~nm}$ by SpecrtoFlex 6600 (WTW, Weilheim, Germany). Blanks, without addition of FDA, were also included to correct for background absorbance and the amount of fluorescein release was determined against a calibration curve. Diversity in microbial metabolism was evaluated by BIOLOG EcoPlates $^{\mathrm{TM}}$ (Biolog, Inc., Hayward, CA, USA) method, based on the discrimination of carbon substrate utilization ability. BIOLOG EcoPlates ${ }^{\mathrm{TM}}$ contain three replicate wells of 31 carbon substrates and a blank in triplicate. As the carbon source is utilized, the tetrazolium violet dye is reduced, developing a purple color. Compost water eluates prepared by vigorously shaking compost at ratio of 1:10 (w/v) for $15 \mathrm{~min}$, were poured into each well of the microplates; then, the plates were incubated at $25^{\circ} \mathrm{C}$ for 4 days in the dark and color development in each well was recorded, $96 \mathrm{~h}$ post inoculum, as the optical density $(\lambda=590 \mathrm{~nm})$ of each well, using the Bio-Rad Microplate Reader 550 (Bio-rad, Inc., Hercules, CA, USA). The assay was conducted as previously described by Bartelt-Ryser et al. [13]. Average well color development (AWCD) was calculated as the sum of activities measured in all wells of each plate, divided by the 31 carbon sources.

\subsection{T-RFLP Analysis}

In order to analyze terminal restriction fragments length polymorphism (T-RFLP), DNA was extracted from composts using the DNeasy Power Soil kit (Qiagen, Germantown, MD, USA) following 
the manufacturer's instructions. Samples with a high content of humic substances were processed by doing two steps with the inhibitor removal buffers designed to precipitate non-DNA organic and inorganic materials. Microbial $16 \mathrm{~S}$ rDNA was PCR amplified with the oligonucleotide pair 27F (5'-AGAGTTTGATCCTGGCTCAG-3') and 1492R (5'-GGTTACCTTGTTACGACTT-3'), with the forward primer labeled with the fluorescent dye FAM (6-carboxyfluorescein) [14]. Reactions were carried out in a final volume of $100 \mu \mathrm{l}$ with $10 \mathrm{ng}$ of DNA template, $1 \times$ PCR buffer containing $2 \mathrm{mM}$ $\mathrm{MgCl}_{2}, 0.2 \mathrm{mM}$ nucleotide mix (abm), 1.25 units of Taq polymerase (DreamTaq, Thermo Scientific) and $2 \mu \mathrm{M}$ of each primer. The amplicons were obtained with the following cycle: $1 \times(94$ for $3 \mathrm{~min}$ ), $35 \times\left(94{ }^{\circ} \mathrm{C}, 30 \mathrm{sec} ; 52^{\circ} \mathrm{C}, 30 \mathrm{sec} ; 72{ }^{\circ} \mathrm{C}, 90 \mathrm{sec}\right), 1 \times\left(72{ }^{\circ} \mathrm{C}, 10 \mathrm{~min}\right)$. Aliquots of $10 \mu \mathrm{l}$ were visualized on $1.2 \%$ agarose gel stained with SYBR safe DNA gel stain (Thermo Fischer Scientific) to assess the presence and the quality of the amplicons before the digestion step. Three restriction enzymes with four-base recognition sequence were used in this work: AluI, HhaI, RsaI (New England Biolabs). A total of $100 \mathrm{ng}$ of purified PCR product was separately digested with $10 \mathrm{U}$ of enzyme at $37^{\circ} \mathrm{C}$ for 3 hours to produce 5' end-labeled 16S rDNA fragments. Complete digestions of PCR products have been verified by running an aliquot $(10 \mu \mathrm{l})$ on an agarose gel, purified and then electrophoretically separated by an ABI Prism 3130 (Applied Biosystems). The lengths and fluorescens of the FAM-labeled terminal restriction fragments ( $t-R F s$ ) were determined by comparison with an internal standard (ROX 500, Applied Biosystems) with a peak height detection of 40 units.

\subsection{Biodiversity Assessment and Statistical Analysis}

Catabolic and t-RFs-based microbial diversity were assessed by alpha-diversity descriptive indexes [15] on the data normalized across all values from the corresponding sample to account for run-to-run variations [16]. Richness (S) was determined by the number of peaks. Shannon diversity index $\left(\mathrm{H}^{\prime}\right)$ was determined using the formula $\mathrm{H}^{\prime}=-\sum(\mathrm{pi})(\ln \mathrm{pi})$, while evenness $\left(\mathrm{J}^{\prime}\right)$ was calculated as $\mathrm{J}^{\prime}=\mathrm{H}^{\prime} / \ln (\mathrm{S})$, and the Simpson index as $(1 / \mathrm{D})=1 / \sum$ pi2, in which, pi is for the relative abundance of each readings and $\ln$ is for the natural log. Comparison of compost control efficacy versus the pathogens, metabolic AWCD index, microbial populations, and fluorescein diacetate hydrolysis (FDAH) between the treatments were done by one-way analysis of variance (ANOVA) and means were separated by Tukey's honestly significant difference (HSD) test at $p \leq 0.05$. Differences in catabolic properties among microbial communities on Biolog substrates were determined by the principal component analysis (PCA). PCA was also performed on the descriptive catabolic and t-RFs diversity indexes, in order to evaluate differences among suppressiveness of composts along the first and third principal components (PC1 and PC3) presented, chosen for the effectiveness of separating the samples. T-RFLP data were square root transformed and similarity matrices were constructed using the Bray-Curtis similarity distance, which is not affected by the number of null values between samples releasing information on Beta-diversity between community compositions for all biological samples [17]. The dataset rank order was examined by nonmetric multi-dimensional scaling (nMDS) to ordinate the similarity data following 100 random starts.

\section{Results}

\subsection{Compost Disease Suppressiveness}

The in vivo suppressive assays showed differential patterns of disease control among composts. Nine out of thirteen raw composts counteracted Rhizoctonia pathogenesis as indicated by damping-off control efficacy in the range of $36-57 \%$, on average. The remaining composts had null effects on disease occurrence. For $S$. minor eight out of thirteen raw composts showed significant control effects between 60 and 95\%, on average (Figure 1). The groups composed of C1, C3, C4, C8, C11, C12 and $\mathrm{C} 13$, and that with $\mathrm{C} 2, \mathrm{C} 5$ and C6 displayed, respectively, the statistically highest $(p \leq 0.05)$ and lowest biocontrol responses on both pathosystems. Conversely, $\mathrm{C} 7$ and $\mathrm{C} 9$ were suppressive against Rhizoctonia damping-off only (Figure 1). The net contribution of the biological component of the 
organic matter in suppressiveness were also measured by comparing raw responses with those of the heated-composts. In general, compost sterilization strongly reduced suppressive properties as shown for seven and nine out of thirteen composts for Rhizoctonia and Sclerotinia damping-off, respectively; providing indications on the specific contribution of biological components on the defined suppressive properties. Surprisingly, C2 increased suppressiveness after sterilization. All on-farm composts showed a significantly $(p \leq 0.05)$ higher percentage of cress germination index than the toxicity threshold value of $80 \%$, indicating the maturity of the compost [18]; C13 had the highest GI\% in comparison with the others (Figure A1 in Appendix A).

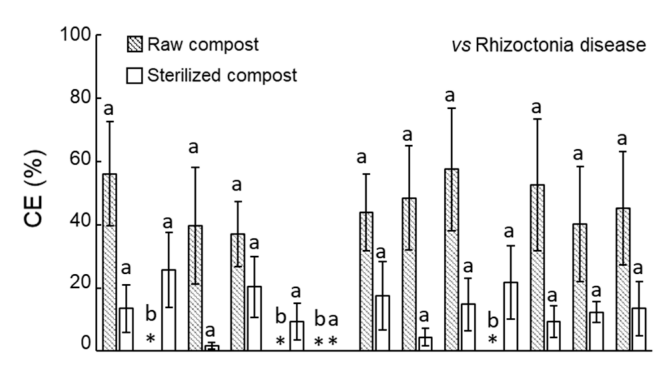

(A)

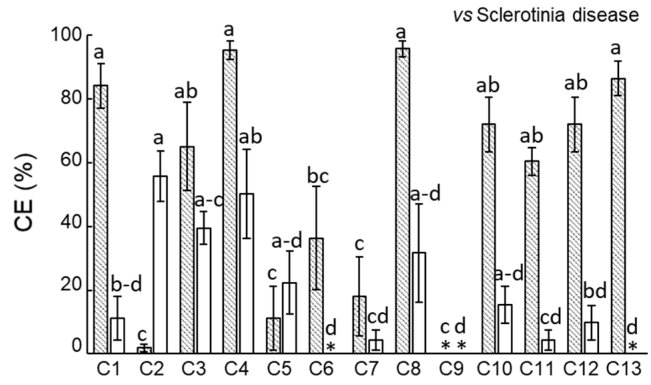

(B)

Figure 1. Control efficacy percentage (CE\%) of raw (grey bars) and autoclaved (open bars) composts (C1-13) on seedling cress damping-off incidence caused by Rhizoctonia solani (A) and Sclerotinia minor (B). Bars indicate the mean \pm standard error. Different letters indicate significant differences among bars of the same color according Tukey's HSD test at $p \leq 0.05$.

\subsection{Compost Microbiological Features}

The microbial community profiles of the composts are displayed in Figure 2. Population levels of


3.21-7.61 $\mathrm{Log}_{\mathrm{CFU} \mathrm{g}}{ }^{-1}$ (Figure 2A,B). FDAH activity was largest for $\mathrm{C} 5$ and $\mathrm{C} 10$ followed, in the rank order, by C8, C2 and C13 (Figure 2C). In Figure 3, the population levels of Bacillus-like and Pseudomonas-like groups are also displayed. Based on the kinetics of color development in Biolog Eco microplates, the average well-color development (AWCD) was highest in C11 followed, in the order, by groups with comparable levels composed of $\mathrm{C} 1$ and C12; C5, C6 and C10; C3 and C8; and the remaining lower samples (Figure 2D).
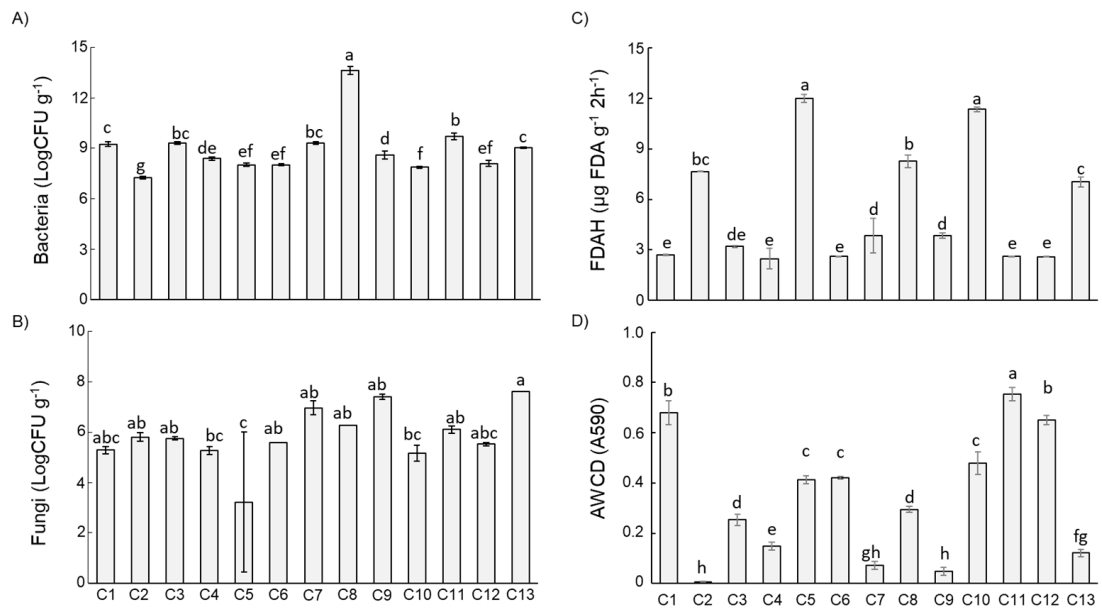

Figure 2. Total bacteria (A) and fungi (B) culturable population levels, (C) fluorescein diacetate hydrolysis (FDAH) and Biolog ${ }^{\circledR}$ EcoPlate $^{\mathrm{TM}}$ (D) average well-color development (AWCD) in the on-farm green composts (C1-13). Bars indicate the mean \pm standard deviation. Different letters indicate significant differences according Tukey's HSD test at $p \leq 0.05$. 
A)

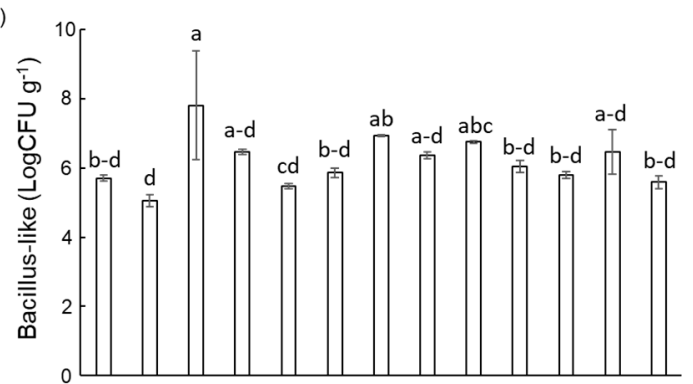

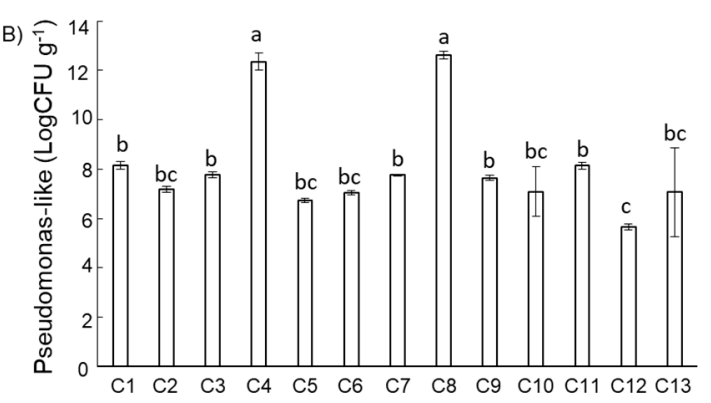

Figure 3. Culturable population levels of total thermoresistant Bacillus-like (A) and Pseudomonas-like (B) bacteria in the on-farm green composts (C1-13). Bars indicate the mean \pm standard deviation.

Different letters indicate significant differences according Tukey's HSD test at $p \leq 0.05$.

\subsection{Microbial Biodiversity}

Principal component analysis of Biolog catabolic activity revealed the highest levels of compost clustering according to the first and the third components, that account together for $42.48 \%$ of the Biolog data variability (Figure 4). PC1 and PC3 have been chosen for the better PC1, explaining $26.34 \%$ of variation, and was correlated $(R>0.60)$ positively with the degree of utilization of tween $40, \alpha$-cyclodextrin, $\mathrm{d}$-xylose, 2-hydroxy benzoic acid, $\gamma$-hydroxybutyric acid, $\alpha$-ketobutyric acid and glycyl-1-glutamic acid; and negatively with $\beta$-methyl-d-glucoside.



Figure 4. Principal component analysis biplot distribution of compost microbial communities on the base of community levels of physiological profiles assessed on Biolog ${ }^{\circledR}$ EcoPlate ${ }^{\mathrm{TM}} \mathrm{C}$-substrates, along the axes of principal component 1 (PC1) and 3 (PC3) describing, respectively, 26.34 and $16.14 \%$ of total data variability.

PC3, accounting for $16.14 \%$ of variation, was positively correlated $(R>0.60)$ with the kinetics of color development on pyruvic acid methyl ester and d-mannitol and negatively with that on putrescine. Ordination biplot in the plane showed that compost communities, on the basis of their C-source utilization capability, form one distinct core group including C1, C4, C5, C8, C10, C11, C12 and C13; whereas composts $\mathrm{C} 3, \mathrm{C} 6, \mathrm{C} 7$ and $\mathrm{C} 9$ are positioned in the first quadrant and $\mathrm{C} 2$ is further away, in the third one.

In order to visualize the dissimilarities in community composition between the samples, as a measure of beta-diversity, nMDS plots were calculated based on the Bray-Curtis dissimilarity index. Overall, nMDS revealed two clearly distinct groups: the most numerous one including the samples $\mathrm{C} 1$, $\mathrm{C} 2, \mathrm{C} 3, \mathrm{C} 4, \mathrm{C} 6, \mathrm{C} 7, \mathrm{C} 8$ and $\mathrm{C} 13$; and those with $\mathrm{C} 10, \mathrm{C} 11$ and $\mathrm{C} 12$ that grouped together. Then, there was a tendency for the samples $\mathrm{C} 5$ and $\mathrm{C} 9$ to position together in the middle of the plot, distinguished from the other samples (Figure 5). 


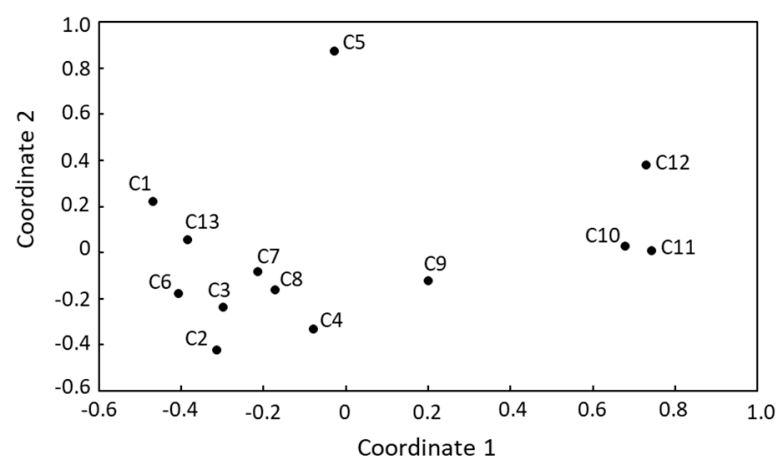

Figure 5. nMDS plot of terminal restriction fragments length polymorphism (T-RFLP) patterns from the different compost samples (C1-13) based on Bray-Curtis similarities in 16S rRNA gene fragments digested with AluI, HhaI and RsaI.

Multivariate correlation analysis by PCA, shows a biplot distribution of the variables, such as alpha-diversity indices and suppressive levels, along the two components PC1 and PC 3 , that may be explained by diversity among samples for $41.83 \%$ and their suppressive properties for $15.14 \%$ of the total variability (Figure 6). Moreover, plane ordination indicated that the functional diversity is most associated with the suppressiveness than the genetic diversity.

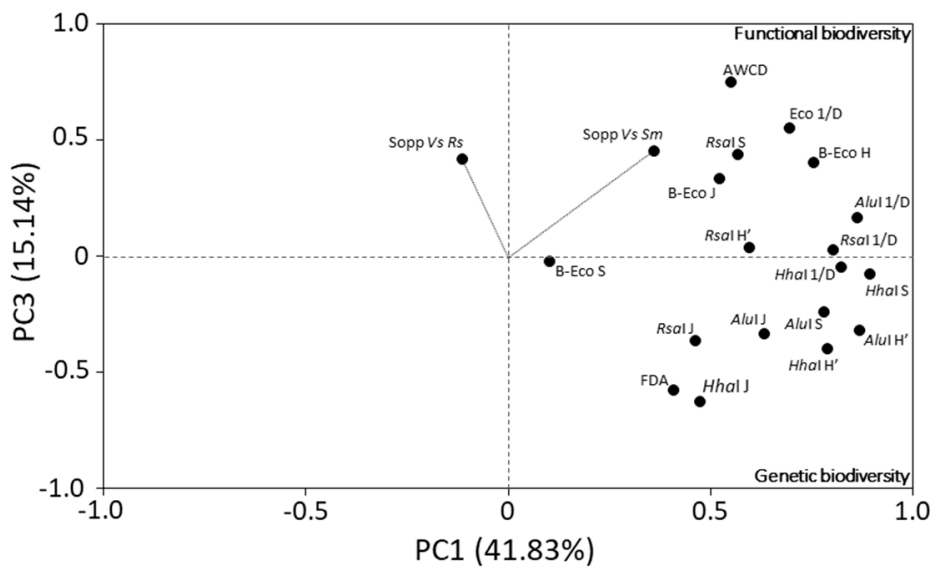

Figure 6. Biplot distribution of descriptive, Richness $(\mathrm{S})$, Shannon $\left(\mathrm{H}^{\prime}\right)$, Evenness $\left(\mathrm{J}^{\prime}\right)$, and Simpson (1/D) diversity indexes, calculated on T-RFLPs produced with AluI, HhaI, RsaI restriction enzymes and Biolog ${ }^{\circledR}$ EcoPlate $^{\mathrm{TM}}$ (B-Eco) community levels of physiological profiles, as revealed by PCA in relation to the suppressive (Sopp) potential of compost microbial communities against the two pathosystems R. Solani (Vs Rs) and S. minor (Vs Sm).

\section{Discussion}

Composts are colonized by a wide spectrum of Procarya and Eukarya microorganisms involved in the breakdown of organic materials on the piles; some of them may potentially play a role in disease suppression [19]. The green waste composts investigated in our study, which varied based on the plant raw material input, showed a differential pattern of suppressiveness over the two assayed pathosystems. Interestingly, suppressiveness was found among compost characterized by a multiple feedstock composition or originated from fennel and artichoke residues, or walnut husk according to previous investigations [8]. Except for C2, sterilization generally diminished or annulled the damping-off control efficacy of these composts, suggesting the decisive role of the microbial biomass in delivering the observed biocontrol functions [20]. C2 is produced by maize and livestock wastes, which could release amounts of ammonia in addition to other fungistatic substances after heating treatment. 
In the current work, microbial population and related activities were not predictors of the recorded suppressiveness, since measures of fungal and bacterial densities, as well as catabolic and enzyme functionalities did not correlate with the compost control efficacy on cress disease. However, some indicative information about antagonistic potentialities of composts may be provided by counts of Bacillus- and Pseudomonas-like groups. On the other hand, alpha-diversity based on differences in microbial C-source metabolizing ability was associated with compost ability to reduce damping-off more than the descriptive diversity indexes calculated on T-RFLPs targeting 16S rRNA gene, as revealed by PCA. Differences in the suppressive potential of composts can be better predicted by the variations in the community levels of physiological profiles. Catabolic-based functions of the resident communities may be used to discriminate suppressive from nonsuppressive composts [9]. Here, PCA separation of compost samples on the basis of the microbial metabolism, evaluated by the Biolog ${ }^{\circledR}$ EcoPlate ${ }^{\mathrm{TM}}$ system, showed one distinct core cluster including the most suppressive composts.

T-RFLP analysis has been used here to characterize a diversity of $16 \mathrm{~S}$ rDNA genes relying on variation in the position of restriction sites among sequences. The beta-diversity described by nMDS analysis of the Bray-Curtis dissimilarity separated the different compost samples into more or less distinct functionally meaningful clusters. Alpha- and beta-diversity of microbial communities indicate the relative differences in the composition of species, respectively, within a single habitat and between habitats [21]. In a compost, these parameters are critically influenced by the conditions occurring during the composting process [22-24], in which microbial communities likely follow a stochastic assembly model [25].

T-RFLP and Biolog Eco Plate are both accepted methods for assessing the complexity of microbial communities in telluric environments $[15,26]$. However, the Biolog ${ }^{\circledR}$ EcoPlate ${ }^{\mathrm{TM}}$ classifies the composts very differently than the T-RFLP pattern and better predicts disease suppression. In the current study a proper involvement of specific healthy microbial community structures [27] in defining disease-suppressive properties of the examined on-farm composts has been revealed. Accordingly, in a previous report, Metha et al. [28] categorized specific selective bacterial structures into compost communities associated with suppressiveness against the Fusarium wilt of tomato.

As a rule, compost suppressiveness follows a general model when it is due to the antagonistic action of the totality of the resident microorganisms, whereas a more specific one when it is based on the effects of individual(s) or select groups [29]. Regulating mechanisms of our suppressive composts resemble the latter.

Microbial diversity may have a crucial role in sustaining ecosystem functions and maintaining the natural suppressive activities via compost amendment [30]. Compost microflora were found to be critical in protecting cucumber seedlings from Fusarium oxysporum f.sp. radicis-cucumerinum [31]. In agroindustrial waste composts, it was linked to the control of the Phytophthora root rot on pepper [32] or the muskmelon fusariosis and Phytophthora blight on pepper [33]. However, the composition and the redundant metabolic functions can dramatically affect these properties. Metabarcoding and GeoChip techniques have been applied to composted almond shell-amended soil samples, revealing an enhancement of specific microbial populations implied in the management of avocado white root rot [34]. De Corato et al. [35] recently demonstrated the transferability of suppressiveness in tailor-made composts by sourcing some potential biocontrol groups from high suppressive green compost extracts. This study agrees with previous reports that found the green feedstock such as cropping residues were able to stimulate the formation of very complex microbial structures during the composting process, more so than the agroindustrial byproducts (i.e., leftovers, production scraps, etc.), involved the specific suppression of a significant group of telluric diseases [36,37].

\section{Conclusions}

Disease suppressive properties of the green composts obtained through the on-farm composting system, constitute an added value of these sustainable products. Levels of physiological profiles, assessed by elaborating communities' ability to consume the BIOLOG Ecoplate differential panel of 
carbon sources, correlated with suppressive functions of the compost samples better than the genetic biodiversity descriptors. Alpha and beta-diversity of microbial compost communities showed how specific selective bacterial structures may be involved in regulating mechanisms of disease biocontrol.

Author Contributions: Conceptualization, C.P., A.D.M., G.C. and M.Z.; methodology, C.P., A.D.M., G.C. and M.Z.; investigation, C.P., R.S. (Roberto Sorrentino), R.S. (Riccardo Scotti), A.D.M., G.C. and M.M.; resources, G.C. and M.Z.; data curation, C.P., R.S. (Roberto Sorrentino), R.S. (Riccardo Scotti), M.M. and A.D.M.; writing-original draft preparation, C.P.; writing-review and editing, C.P., R.S. (Roberto Sorrentino), R.S. (Riccardo Scotti), M.M., A.D.M., G.C. and M.Z.; supervision, M.Z.; project administration, M.Z.; funding acquisition, M.Z. All authors have read and agreed to the published version of the manuscript.

Funding: This research was funded by EU LIFE+ program through the project "Technologies for the stabilization of organic carbon and improving the productivity of agricultural land, for the exploitation of biomass and mitigation of climate change-CarbOnFarm" (LIFE12ENV/IT/000719).

Acknowledgments: The authors would like to thank Felice Contaldi for helping to perform bioinformatic analyses.

Conflicts of Interest: The authors declare no conflict of interest.

\section{Appendix A}

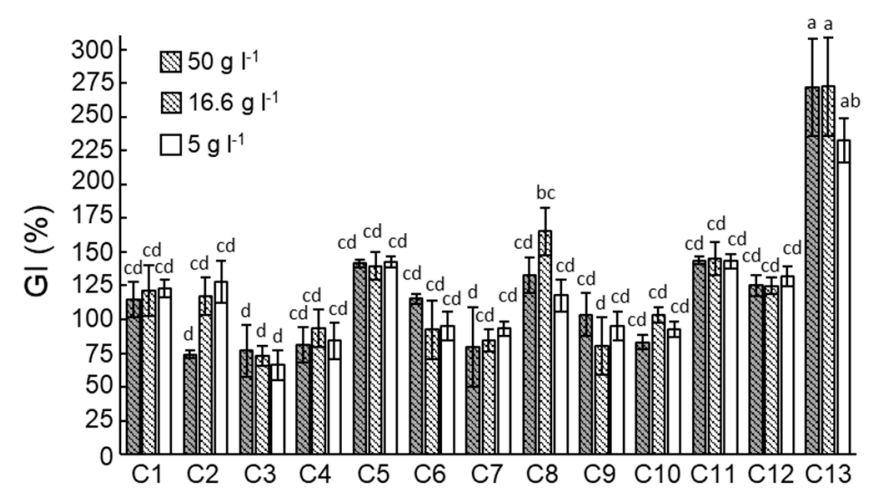

Figure A1. Compost phytotoxicity index. Evaluation of the cress germination index (GI\%) on water extracts of composts (C1-13) at high, medium and low concentrations $\left(50,16.6\right.$ and $5 \mathrm{gl}^{-1}$, respectively). Bars indicate the mean \pm standard error. Different letters indicate significant differences among bars of the same concentration according Tukey's HSD test at $p \leq 0.05$.

\section{References}

1. Bonilla, N.; Gutiérrez-Barranquero, J.A.; Vicente, A.D.; Cazorla, F.M. Enhancing soil quality and plant health through suppressive organic amendments. Diversity 2012, 4, 475-491. [CrossRef]

2. Pane, C.; Spaccini, R.; Piccolo, A.; Scala, F.; Bonanomi, G. Compost amendments enhance peat suppressiveness to Pythium ultimum, Rhizoctonia solani and Sclerotinia minor. Biol. Control 2011, 56, 115-124. [CrossRef]

3. Hadar, Y.; Papadopoulou, K.K. Suppressive composts: Microbial ecology links between abiotic environments and healthy plants. Annu. Rev. Phytopathol. 2012, 50, 133-153. [CrossRef] [PubMed]

4. Stavi, I.; Bel, G.; Zaady, E. Soil functions and ecosystem services in conventional, conservation, and integrated agricultural systems. A review. Agron. Sustain. Dev. 2016, 36, 32. [CrossRef]

5. Adhikari, K.; Hartemink, A.E. Linking soils to ecosystem services-A global review. Geoderma 2016, 262, 101-111. [CrossRef]

6. Pal, K.K.; McSpadden Gardener, B. Biological Control of Plant Pathogens. In The Plant Health Instructor; APSnet: Saint Paul, MN, USA, 2006; pp. 1-25.

7. Scotti, R.; Pane, C.; Spaccini, R.; Palese, A.M.; Piccolo, A.; Celano, G.; Zaccardelli, M. On-farm compost: A useful tool to improve soil quality under intensive farming systems. Appl. Soil Ecol. 2016, 107, 13-23. [CrossRef]

8. Pane, C.; Piccolo, A.; Spaccini, R.; Celano, G.; Villecco, D.; Zaccardelli, M. Agricultural waste-based composts exhibiting suppressivity to diseases caused by the phytopathogenic soil-borne fungi Rhizoctonia solani and Sclerotinia minor. Appl. Soil Ecol. 2013, 65, 43-51. [CrossRef] 
9. Pane, C.; Spaccini, R.; Piccolo, A.; Celano, G.; Zaccardelli, M. Disease suppressiveness of agricultural greenwaste composts as related to chemical and bio-based properties shaped by different on-farm composting methods. Biol. Control 2019, 137, 104026. [CrossRef]

10. Scotti, R.; Bertora, C.; Pastore, V.; Antonucci, M.; Pane, C.; Gaudino, S.; Persiani, A.; Sorrentino, R.; Di Meo, V.; Grignani, C.; et al. Life Carbonfarm project: Technologies to stabilize soil organic carbon and farm productivity, promote waste value and climate change mitigation. In Proceedings of the Global Symposium on Soil Organic Carbon, Rome, Italy, 21-23 March 2017.

11. Nakasaki, K.; Hirai, H.; Mimoto, H.; Quyen, T.N.M.; Koyama, M.; Takeda, K. Succession of microbial community during vigorous organic matter degradation in the primary fermentation stage of food waste composting. Sci. Total Environ. 2019, 671, 1237-1244. [CrossRef]

12. Shin, T.S.; Yu, N.H.; Lee, J.; Choi, G.J.; Kim, J.C.; Shin, C.S. Development of a biofungicide using a mycoparasitic fungus Simplicillium lamellicola BCP and its control efficacy against gray mold diseases of tomato and ginseng. Plant Pathol. J. 2017, 33, 337-344. [CrossRef]

13. Bartelt-Ryser, J.; Joshi, J.; Schmid, B.; Brandl, H.; Balser, T. Soil feedbacks of plant diversity on soil microbial communities and subsequent plant growth. Perspect. Plant Ecol. Evol. Syst. 2005, 7, 27-49. [CrossRef]

14. Amann, R.I.; Ludwig, W.; Schleifer, K.H. Phylogenetic identification and in situ detection of individual microbial cells without cultivation. Microbiol. Rev. 1995, 59, 143-169. [CrossRef] [PubMed]

15. Tipayno, S.; Kim, C.G.; Sa, T. T-RFLP analysis of structural changes in soil bacterial communities in response to metal and metalloid contamination and initial phytoremediation. Appl. Soil Ecol. 2012, 61, 137-146. [CrossRef]

16. Babendreier, D.; Joller, D.; Romeis, J.; Bigler, F.; Widmer, F. Bacterial community structures in honeybee intestines and their response to two insecticidal proteins. FEMS Microbiol. Ecol. 2007, 59, 600-610. [CrossRef]

17. Blaud, A.; Diouf, F.; Herrmann, A.M.; Lerch, T.Z. Analysing the effect of soil organic matter on bacterial communities using T-RFLP fingerprinting: Different methods, different stories? Biol. Fertil. Soils 2015, 51, 959. [CrossRef]

18. Zucconi, F.; Pera, A.; Forte, M.; de Bertoldi, M. Evaluating toxicity of immature compost. BioCycle 1981, 22, $54-57$.

19. Hadar, Y. Suppressive compost: When plant pathology met microbial ecology. Phytoparasitica 2011, $39,311$. [CrossRef]

20. Malandraki, I.; Tjamos, S.E.; Pantelides, I.S.; Paplomatas, E.J. Thermal inactivation of compost suppressiveness implicates possible biological factors in disease management. Biol. Control 2008, 44, 180-187. [CrossRef]

21. Flores-Rentería, D.; Rincón, A.; Valladaresa, F.; Curiel Yuste, J. Agricultural matrix affects differently the alpha and beta structural and functional diversity of soil microbial communities in a fragmented Mediterranean holm oak forest. Soil Biol. Biochem. 2016, 92, 79-90. [CrossRef]

22. Robledo-Mahón, T.; Aranda, E.; Pesciaroli, C.; Rodríguez-Calvo, A.; Silva-Castro, G.A.; González-López, J. Effect of semi-permeable cover system on the bacterial diversity during sewage sludge composting. J. Environ. Manag. 2018, 215, 57-67. [CrossRef]

23. Cao, G.; Song, T.; Shen, Y.; Jin, Q.; Feng, W.; Fan, L.; Cai, W. Diversity of bacterial and fungal communities in wheat straw compost for Agaricus bisporus cultivation. HortScience 2019, 54, 100-109. [CrossRef]

24. Esan, E.O.; Abbey, L.; Yurgel, S. Exploring the long-term effect of plastic on compost microbiome. PLoS ONE 2019, 14, e0214376. [CrossRef] [PubMed]

25. Xun, W.; Li, W.; Xiong, W.; Ren, Y.; Liu, Y.; Miao, Y.; Xu, Z.; Zhang, N.; Shen, Q.; Zhang, R. Diversity-triggered deterministic bacterial assembly constrains community functions. Nat. Commun. 2019, 10, 3833. [CrossRef] [PubMed]

26. Rutgers, M.; Wouterse, M.; Drost, S.M.; Breure, A.M.; Mulder, C.; Stone, D.; Creamer, R.E.; Winding, A.; Bloem, J. Monitoring soil bacteria with community-level physiological profiles using Biolog ${ }^{\mathrm{TM}}$ ECO-plates in the Netherlands and Europe. Appl. Soil Ecol. 2016, 97, 23-35. [CrossRef]

27. Zhou, D.; Jing, T.; Chen, Y.; Wang, F.; Qi, D.; Feng, R.; Xie, J.; Li, H. Deciphering microbial diversity associated with Fusarium wilt-diseased and disease free banana rhizosphere soil. BMC Microbiol. 2019, 19, 161. [CrossRef] [PubMed]

28. Mehta, C.M.; Pudake, R.N.; Srivastava, R.; Palni, U.; Sharma, A.K. Development of PCR-based molecular marker for screening of disease-suppressive composts against Fusarium wilt of tomato (Solanum lycopersicum L.). 3 Biotech 2018, 8, 306. [CrossRef] [PubMed] 
29. Weller, D.M.; Raaijmakers, J.M.; McSpadden Gardener, B.B.; Thomashow, L.S. Microbial populations responsible for specific soil suppressiveness to plant pathogens. Annu. Rev. Phytopathol. 2002, 40, 309-348. [CrossRef]

30. Zaccardelli, M.; De Nicola, F.; Villecco, D.; Scotti, R. The development and suppressive activity of soil microbial communities under compost amendment. J. Soil Sci. Plant Nutr. 2013, 13, 730-742. [CrossRef]

31. Cao, Y.; Tian, Y.; Gao, Y.; Li, J. Microbial diversity in compost is critical in suppressing plant fungal pathogen survival and enhancing cucumber seedling growth. Compost Sci. Util. 2018, 26, 189-200. [CrossRef]

32. Blaya, J.; Marhuenda, F.C.; Pascual, J.A.; Ros, M. Microbiota characterization of compost using omics approaches opens new perspectives for Phytophthora root rot control. PLoS ONE 2016, 11, e0158048. [CrossRef]

33. Blaya, J.; Lloret, E.; Ros, M.; Pascual, J.A. Identification of predictor parameters to determine agro-industrial compost suppressiveness against Fusarium oxysporum and Phytophthora capsici diseases in muskmelon and pepper seedlings. J. Sci. Food Agric. 2014, 95, 1482-1490. [CrossRef] [PubMed]

34. Vida, C.; Bonilla, N.; de Vicente, A.; Cazorla, F.M. Microbial profiling of a suppressiveness-induced agricultural soil amended with composted almond shells. Front Microbiol. 2016, 7, 4. [CrossRef] [PubMed]

35. De Corato, U.; Salimbeni, R.; De Pretis, A.; Patruno, L.; Avella, N.; Lacolla, G.; Cucci, G. Microbiota from 'next-generation green compost' improves suppressiveness of composted Municipal-Solid-Waste to soil-borne plant pathogens. Biol. Control 2018, 124, 1-17. [CrossRef]

36. De Corato, U.; Patruno, L.; Avella, N.; Lacolla, G.; Cucci, G. Composts from green sources show an increased suppressiveness to soilborne plant pathogenic fungi: Relationships between physiochemical properties, disease suppression, and the microbiome. Crop Prot. 2019, 124, 104870. [CrossRef]

37. Pane, C.; Zaccardelli, M. Principles of compost-based plant diseases control and innovative new developments. In Composting for Sustainable Agriculture; Maheshwari, D.K., Ed.; Springer International Publishing: Berlin/Heidelberg, Germany, 2014; Volume 3, pp. 151-171.

(C) 2020 by the authors. Licensee MDPI, Basel, Switzerland. This article is an open access article distributed under the terms and conditions of the Creative Commons Attribution (CC BY) license (http://creativecommons.org/licenses/by/4.0/). 